\title{
Induction of Apoptosis in HL-60 Human Promyelocytic Leukemia Cells by Adenosine $A_{3}$ Receptor Agonists
}

\author{
Yutaka Kohno*, Yoshitatsu Sei ${ }^{\dagger}$, Masahiro Koshiba ${ }^{\ddagger}$, Hea O. Kim ${ }^{\star}$, and Kenneth A. \\ Jacobson ${ }^{*}, 1$ \\ "Molecular Recognition Section, Laboratory of Bioorganic Chemistry, National Institutes of Health, \\ Bethesda, Maryland 20892 \\ †Laboratory of Neuroscience, NIDDK, National Institutes of Health, Bethesda, Maryland 20892 \\ ҒLaboratory of Immunology, NIAID, National Institutes of Health, Bethesda, Maryland 20892
}

\section{Abstract}

The effects of adenosine (ADO) analogs on cells of the human promyelocytic HL-60 line were examined. $\mathrm{ADO} \mathrm{A}_{3}$ receptor agonists, $\mathrm{N}^{6}-(3$-iodobenzyl) adenosine-5'-N-methylcarboxamide (IBMECA, 30-60 $\mu \mathrm{M}$ ) and 2-chloro- $\mathrm{N}^{6}$-(3-iodobenzyl) adenosine-5'-N-methyluronamide (CI-IBMECA, 10-30 $\mu \mathrm{M}$ ) induced apoptotic cell death. In contrast, neither an $\mathrm{A}_{1} / \mathrm{A}_{2}$ antagonist (XAC) nor other selective ADO receptor agonists (CPA, NECA and CGS21680) induced apoptosis at concentrations of $\leq 30 \mu \mathrm{M}$. Both IB-MECA and CI-IB-MECA significantly induced $\mathrm{Ca}^{2+}$ release from intracellular $\mathrm{Ca}^{2+}$ pools followed by $\mathrm{Ca}^{2+}$ influx, suggesting the presence of phospholipase C-coupled $\mathrm{ADO} \mathrm{A}_{3}$ receptors on HL-60 cells. This was further supported by the presence of mRNA of ADO A3 receptor in the cells. These results suggest that activation of $\mathrm{ADO} \mathrm{A}_{3}$ receptors is responsible for the ADO-induced apoptosis in HL-60 cells and could be of potential therapeutic value in the treatment of leukemia.

\begin{abstract}
ADO regulates a variety of physiological effects on numerous cell types through activation of membrane-bound adenosine receptors. These have recently been classified into four distinct subtypes, $A_{1}, A_{2 a}, A_{2 b}$ and $A_{3}$ (1). In particular, recent evidence indicates that these $\mathrm{ADO}$ receptors play roles in regulating development of cells by inducing apoptotic cell death (2-4). Apoptosis is an active self-destruction caused by activating a genetically programmed cascade of molecular events. This process leads to DNA degradation and death of the cell via nuclear and cytoplasmic breakup, packaging into apoptotic bodies, etc. $(5,6)$. In thymus, this process is essential for the development of T cells. ADO has recently been proposed to be involved in controlling the positive/negative selection of human thymocytes in relatively later stages of $\mathrm{T}$ cell development $(2,3)$. Thus, ADO induces apoptosis in mature $\mathrm{CD} 3^{+} \mathrm{CD} 4^{-} \mathrm{CD} 8^{+}$cells, as well as corticosteroid-sensitive $\mathrm{CD} 4^{+} \mathrm{CD} 8^{+}$cells. These effects appear to be mediated by ADO receptors, since both $A_{1}$ and $A_{2}$ receptor agonists produced DNA fragmentation in these cells.
\end{abstract}

\footnotetext{
${ }^{1}$ To whom correspondence should be addressed at Bldg. 8A, Rm. B1A-17, NIDDK/NIH, Bethesda, MD 20892. Fax: (301) 480-8422.
} 
In addition to the significant effects of ADO on thymocytes, recent report also showed that human promyelocytic HL-60 cells undergo apoptosis in response to treatment with ADO (4). HL-60 cells have been used extensively as an in vitro model for neutrophil function, because of their ability to differentiate into both functionally and morphologically mature myeloid cells $(7,8)$. Moreover, because a variety of chemicals, radiation and hyperthermia induce apoptosis $(4,9,10)$, this model is also useful to study mechanisms of apoptosis of differentiating cells in myelocytic lineage. Tanaka et al. (4) indicated that ADO but not other naturally occurring nucleosides induced apoptosis in HL-60 cells. Curiously, selective ADO receptor agonists failed to induce apoptosis in these cells, thus the authors concluded that ADO-induced apoptosis in HL-60 cells is not likely mediated by ADO-receptors. However, these authors did not take into account the novel $\mathrm{A}_{3}$ adenosine receptor, since selective agents for this subtype were not available until recently (11). The present study indicates that selective $\mathrm{ADO} \mathrm{A}_{3}$ receptor agonists, IB-MECA (11) and CI-IB-MECA (12) synthesized in our laboratory, induced receptor-mediated $\mathrm{Ca}^{2+}$ influx as well as apoptotic cell death in HL-60 cells.

\section{MATERIALS AND METHODS}

\section{Reagents}

RPM 1640 medium and fetal bovine serum were obtained from Gibco BRL (Gaithersburg, MD). Erythro-9-(2-hydroxy-3-nonyl)adenine hydrochloride (EHNA). ADO, XAC, CPA, NECA and CGS21680 were purchased from RBI (Natick, MA). Highly selective ADO $\mathrm{A}_{3}$ agonists, IB-MECA (11) and CI-IB-MECA (12), were synthesized in our laboratory. Chromomycin A3 was purchased from Sigma Chemical (St. Louis. MO).

\section{Cell cultures and preparations}

The HL-60 cells were maintained in RPMI 1640 supplemented with $10 \%$ fetal calf serum. 100 units $/ \mathrm{ml}$ penicillin. $100 \mathrm{mg} / \mathrm{ml}$ streptomycin and $2 \mathrm{mM} \mathrm{L}$-glutamine. The cells were split every third day, and 2 days before each experiment cultures were diluted to $2 \times 10^{5}$ cells $/ \mathrm{ml}$. For analysis of DNA content, aliquots of $2 \mathrm{ml}$ were placed into 12-well flatbottomed plates (Costar, Cambridge, MA, USA) containing $2 \sim 6 \mu$ l test-compound solutions at defined concentrations or $6 \mu \mathrm{DMSO}$ (diluting medium).

\section{DNA content analysis by flow cytometry}

Cells were fixed by adding $\sim 10^{7}$ cells suspended in $1 \mathrm{ml}$ of PBS to $1 \mathrm{ml} 80 \%$ ethanol at $-20^{\circ} \mathrm{C}$ and stored for $48-120 \mathrm{hrs}$. After the cells were washed twice with PBS, the cells were stained with $20 \mathrm{mg} / \mathrm{ml}$ chromomycin A3 dissolved in PBS containing $2 \mathrm{mM} \mathrm{MgCl}_{2}$ by incubation in subdued light $\left(30 \mathrm{~min} ; 4^{\circ} \mathrm{C}\right)$. The cells were then analyzed using a FACScan flow cytometer (Becton Dickinson, Mountain View, CA) as previously described (13).

\section{DNA gel electrophoresis}

DNA fragmentation was analyzed as previously described (14). In brief, cells were washed twice with PBS at $4^{\circ} \mathrm{C}$, resuspended in lysis buffer $(5 \mathrm{mM}$ Tris- $\mathrm{HCl}, \mathrm{pH}$ 8.0, $20 \mathrm{mM}$ EDTA tetrasodium salt tetrahydrate and $0.5 \%$ Triton $\mathrm{X}$ ) and homogenized with a disposable Dounce homogenizer (Kontes, Vineland, NJ). Homogenates were incubated for 2 hours at 
$4^{\circ} \mathrm{C}$ and centrifuged at $15000 \mathrm{~g}\left(4^{\circ} \mathrm{C}\right)$. The supernatants were collected and treated with 100 $\mu \mathrm{g} / \mathrm{ml}$ proteinase $\mathrm{K}$ (Boehringer Mannheim, Indianapolis, IN) for 1 hour at $56^{\circ} \mathrm{C}$. Following phenol/chloroform extraction and ethanol precipitation, the DNA samples were resuspended in deionized water, treated with Rnase $(100 \mu \mathrm{g} / \mathrm{ml})$, and electrophoresed on $1 \%$ agarose gel. A molecular weight standard run in parallel consisted of $\phi$ X174 RF DNA/Hae III fragments (Life Technologies, Gaitherburg, MD).

\section{RT-PCR analysis}

Total RNA was prepared by the single-step method (15) with slight modifications (RNA Stat-60, Tel-Test "B", Inc., Friendswood, TX). One $\mu \mathrm{g}$ of total RNA was incubated at room temperature for 15 min with 1 unit of RNase-free DNase 1 (Boehringer Mannheim, Indianapolis, IN), and the first strand cDNA was synthesized with $0.5 \mu \mathrm{g}$ of oligo (dT) ${ }_{12-18}$ primer and 200 units of the cloned M-MLV reverse transcriptase (SUPERSCRIPT II preamplification system. Life Technologies, Gaithersburg, MD).

The human $\mathrm{A}_{3} \mathrm{ADO}$ receptor sequence was amplified with $5^{\prime}$ primer sequence (ACCCCCATGTTTGGCTG) and $3^{\prime}$ primer sequence (GCACAAGCTGTGGTACCTCA) giving a $361 \mathrm{bp}$ product $(16,17)$. PCR was carried out in $50 \mu \mathrm{l}$ and at the following conditions: the initial denaturing step at $95^{\circ} \mathrm{C}$ for $2 \mathrm{~min}$, followed by 35 cycles of $94^{\circ} \mathrm{C}$ for $30 \mathrm{~s} .55^{\circ} \mathrm{C}$ for $30 \mathrm{~s}, 72^{\circ} \mathrm{C}$ for $30 \mathrm{~s}$, except the last elongation at $72^{\circ} \mathrm{C}$ for $10 \mathrm{~min}$. Subsequently, $10 \mu \mathrm{l}$ of PCR products were run on the $4 \%$ NuSieve 3:1 agarose gel (FMC BioProducts, Rockland, ME) and examined by ethidium bromide staining.

\section{Measurement of cytosolic $\mathrm{Ca}^{2+}$ concentration}

HL-60 cells $\left(10^{6} \mathrm{cells} / \mathrm{ml}\right)$ were incubated in the presence of $1 \mu \mathrm{g}$ fluo-3AM in a 1:1 mixture of RPMI 1640 and Hanks' balanced salt solution (HBSS) buffer for 40 min at room temperature.

The cells were suspended in a 1:1 mixture of RPMI medium and HBSS buffer at about $10^{6}$ cells $/ \mathrm{ml}$. Ten $\mathrm{ml}$ of a DMSO solution containing $1 \mu \mathrm{g} / \mathrm{ml}$ of fluo-3 AM (Molecular Probes, Inc., Eugene OR) was added to $10 \mathrm{ml}$ of the cell suspension, and cells were left in the dark for $40 \mathrm{~min}$ at room temperature. The cells were centrifuged at $1200 \mathrm{rpm}$ for $10 \mathrm{~min}$ to remove extracellular dye and resuspended in HBSS. Two $\mathrm{ml}$ of cell suspension was added to each cuvette with a magnetic stir bar, and the fluorescence intensity of fluo-3 AM was quantified using a Deltascan fluorescence spectrophotometer (Photon Technology International, Inc., Brunswick, NJ) with the excitation wavelength set at $506 \mathrm{~nm}$ and emission wavelength monitored at $526 \mathrm{~nm}$. The maximum fluo-3 fluorescence (F max) in HL-60 cells was determined by adding Triton-X $(0.025 \%)$ or 4-bromoA23187 $(1 \mu \mathrm{M})$ in the presence of $1 \mathrm{mM} \mathrm{Ca}^{2+}$. The minimum fluorescence ( $\mathrm{F} \mathrm{min}$ ) was determined following quenching of fluo-3 with $0.5 \mathrm{mM}$ EDTA.

\section{RESULTS AND DISCUSSION}

Fig. 1 shows the changes in DNA frequency distribution histograms of HL-60 cells exposed to the $\mathrm{A}_{3}$ receptor agonists, IB-MECA $(10,30$, or $60 \mu \mathrm{M})$ and CI-IB-MECA $(10$ or $30 \mu \mathrm{M})$, for $48 \mathrm{hrs}$. The DNA frequency histogram shows that the treatment with IB-MECA or CI- 
IB-MECA at 10 or $30 \mu \mathrm{M}$ produced cells with hypodiploid DNA content. XAC $(50 \mu \mathrm{M})$ did not inhibit the DNA fragmentation induced by CI-IB-MECA (data not shown). This DNA fragmentation is typical of apoptosis, thus the $\mathrm{A}_{3}$ receptor agonists induced apoptosis in these cells. This finding is consistent to the results of DNA gel electrophoresis (Fig. 2) which show that HL-60 cells revealed internucleosomal DNA fragmentation when cells were cultured with $30 \mu \mathrm{M}$ CI-IB-MECA or $30 \mu \mathrm{M}$ CADO for $48 \mathrm{hr}$. The same results were observed when the cells were incubated for $48 \mathrm{hr}$ with $150 \mathrm{nM}$ camptothecin as an active control (Fig. 2), as was shown previously in HL-60 cells (18). ADO alone at a concentration of $100 \mu \mathrm{M}$ did not induce apoptosis (data not shown), but in the presence of $100 \mu \mathrm{M}$ EHNA, an ADO deaminase inhibitor, apoptosis occurred (Fig. 1B).

The ADO receptor agonists, CPA ( $\mathrm{A}_{1}$-selective), NECA (non-selective), and CGS21680 $\left(\mathrm{A}_{2 \mathrm{a}}\right.$-selective), and an $\mathrm{ADO} \mathrm{A}_{1} / \mathrm{A}_{2}$ antagonist, $\mathrm{XAC}$, did not induce apoptosis at concentrations of $10-50 \mu \mathrm{M}$ (data not shown).

CADO (an $\mathrm{A}_{1}$ agonist of low selectivity) also elicited apoptosis at $10 \mu \mathrm{M}$ (Fig. 1E). However, XAC $(50 \mu \mathrm{M})$ had no effect on frequency of cells with fractional DNA content induced by CADO (data not shown).

The RT-PCR analysis clearly indicated the expression of $\mathrm{ADO} \mathrm{A}_{3}$ receptor mRNA in the HL-60 cells. Analysis of cDNA, using primers designed to specifically amplify a fragment of the human $\mathrm{A}_{3}$ receptor cDNA, revealed the expected 361-bp PCR product (Fig. 3). No signal for the human $\mathrm{A}_{3}$ receptor was detected in the control without reverse-transcriptase (Lane 3), or in another lane (4) in which water was substituted for the cDNA (Fig. 3).

$\mathrm{A}_{3}$ receptor agonists, IB-MECA and CI-IB-MECA (10 and $\left.30 \mu \mathrm{M}\right)$, produced increases in concentrations of intracellular free $\mathrm{Ca}^{2+}\left(\left[\mathrm{Ca}^{2+}\right]_{\mathrm{i}}\right)$ (Fig. 4A). Both drugs produced a rapid rise followed by a sustained increase in $\left[\mathrm{Ca}^{2+}\right]_{\mathrm{i}}$. Chelation of extracellular $\mathrm{Ca}^{2+}$ with EGTA $(0.5 \mathrm{mM})$ did not affect the initial rise in $\left[\mathrm{Ca}^{2+}\right]_{\mathrm{i}}$ but attenuated a second phase of elevations in $\left[\mathrm{Ca}^{2+}\right]_{\mathrm{i}}$. Thus, the first rapid increase in $\left[\mathrm{Ca}^{2+}\right]_{\mathrm{i}}$ was due to $\mathrm{Ca}^{2+}$ release from intracellular $\mathrm{Ca}^{2+}$ pools, while the second phase appeared to result from an influx of extracellular $\mathrm{Ca}^{2+}$ (Fig. 4A). Although NECA $(30 \mu \mathrm{M})$ and CADO $(30 \mu \mathrm{M})$ tended to induce an increase in intracellular $\mathrm{Ca}^{2+}$ levels, the intensity of the elevation of $\left[\mathrm{Ca}^{2+}\right]_{\mathrm{i}}$ was clearly lower than that of CI-IB-MECA (30 $\mu \mathrm{M})$. At concentrations of $30 \mu \mathrm{M}, \mathrm{CPA}, \mathrm{CGS} 21680$ and XAC had no effect on intracellular $\mathrm{Ca}^{2+}$ levels (data not shown).

In the present study we have examined the effect of $\mathrm{ADO}$ and a variety of its analogs on HL-60 cells. ADO $(100 \mu \mathrm{M})$ in the presence of an ADO deaminase inhibitor, EHNA (100 $\mu \mathrm{M})$, caused apoptosis (Fig. 1). However, ADO receptor agonists CPA ( $\mathrm{A}_{1}$-selective) and CGS21680 ( $\mathrm{A}_{2}$-selective $)$ did not have any detectable effects on the cells. Also, the nonselective $A_{1}, A_{2 a}$ agonist NECA did not induce apoptosis. Therefore, the $A_{1}, A_{2 a}$ or $A_{2 b}$ $\mathrm{ADO}$ receptor(s) alone do not seem to be involved in the cell death. These findings are consistent with the results obtained by Tanaka et al (4). However, in the concentration range of 10 30 $\mu \mathrm{M}$, selective ADO $\mathrm{A}_{3}$ receptor agonists, IB-MECA and CI-IB-MECA, apparently induced apoptosis. CI-IB-MECA was more potent in inducing apoptosis than IB-MECA. The concentrations required for eliciting apoptosis in HL-60 cells are considerably higher 
than the $\mathrm{IC}_{50}$ values $\left(\sim 10^{-7} \mathrm{M}\right)$ for rat $\mathrm{A}_{3}$-receptor mediated adenylyl cyclase (12), possibly reflecting differences between whole cells and membranes or between species. The affinity of NECA, which did not induce apoptosis, at $\mathrm{A}_{3}$ receptors is >100-fold lower than IBMECA (24). Two lines of evidence suggest the presence of functional ADO $\mathrm{A}_{3}$ receptors on HL-60 cells. First, both IB-MECA and CI-IB-MECA produced $\mathrm{Ca}^{2+}$ release from the intracellular $\mathrm{Ca}^{2+}$ pools followed by a sustained $\mathrm{Ca}^{2+}$ influx, which is typical of phospholipase $\mathrm{C}$-coupled receptor-mediated $\mathrm{Ca}^{2+}$ response. A phospholipase $\mathrm{C}$-coupled $\mathrm{ADO} \mathrm{A}_{3}$ receptor-mediated $\mathrm{Ca}^{2+}$ response has also been demonstrated in rat basophilic cells (RBL-2H3) (19), and $\mathrm{A}_{3}$ agonists were found to activate phospholipase $\mathrm{C}$ in rat brain slices (29). Second, the mRNA of ADO $\mathrm{A}_{3}$ receptor is apparently expressed in the HL-60 cells. Therefore, overall results suggest that activation of $\mathrm{ADO} \mathrm{A}_{3}$ receptors is responsible for ADO-induced apoptosis in HL-60 cells.

In apparent contradiction to the above hypothesis, $\mathrm{CADO}$, an $\mathrm{A}_{1}$ agonist of low selectivity, was able to induce apoptosis in HL-60 cells, as it was recently reported to do also in thymocytes (3) and in astroglial cells in rat brain primary cultures (20). Since CADO (26, 27) is equipotent to NECA at $A_{1}$ receptors $(9.3$ vs. $6.3 \mathrm{nM})$ and less potent than NECA at $\mathrm{A}_{2 \mathrm{a}}(63 \mathrm{vs} .10 \mathrm{nM}), \mathrm{A}_{2 \mathrm{~b}}(24$ vs. $2.6 \mu \mathrm{M})$, and $\mathrm{A}_{3}(1890$ vs. $113 \mathrm{nM})$ receptors, it is likely that the mechanism of apoptosis induced by CADO is not via adenosine receptors. Tanaka et al. (4) observed an effect of ADO but not CADO on polyADP ribosylation activity in HL-60 cells, further supporting distinct mechanisms for cell death induced by these two analogues. The hypothesis of a non- $\mathrm{A}_{1} / \mathrm{A}_{2}$ receptor-mediated pathway for the action of CADO is further supported by our finding that an $\mathrm{ADO} \mathrm{A}_{1} / \mathrm{A}_{2}$ antagonist XAC had no effect on CADO-induced apoptosis in HL-60 cells. It is also noteworthy that a closely related compound, 2-chloro-2'-deoxyadenosine (cladribine), also induces apoptosis in leukemic cells (28), probably in an ADO receptor-independent fashion since it binds only very weakly to the receptors (26). Cladribine is currently being used in the treatment of leukemia (21). Detailed mechanisms responsible for the induction of apoptosis by either CADO or $\mathrm{A}_{3}$ agonists are now under investigation.

Recent studies have identified a novel adenosine receptor subtype, $\mathrm{A}_{3}$, in the rat (22) and similar receptors have been cloned from both human (17) and sheep brain cDNA libraries (23). Few physiological functions of $\mathrm{ADO} \mathrm{A}_{3}$ receptor are known (24). In particular with respect to immunologic function, there is little information available except the reports cited that activation of $\mathrm{A}_{3}$ receptors regulates function in basophilic cells (19) and mast cells (25). Further elucidation of the mechanisms and control of apoptosis in hematopoietic cells is likely to shed new light on the pathophysiology of inflammation and suggest new approaches to the therapy of inflammatory diseases and leukemia.

\section{Abbreviations used}

$\begin{array}{ll}\text { ADO } & \text { adenosine } \\ \text { CADO } & \text { 2-chloroadenosine }\end{array}$


CGS 21680 2-[4-[(2-carboxyethyl)-phenyl]ethylamino]-5' Nethylcarboxamidoadenosine

CI-IB-MECA N $\mathrm{N}^{6}$-(3-iodobenzyl)-2-chloro-adenosine-5'-N-methyluronamide

CPA

$\mathrm{N}^{6}$-cyclopentyladenosine

IB-MECA $\quad \mathrm{N}^{6}$-(3-iodobenzyl)adenosine-5'-N-methyluronamide

NECA 5'-N-ethylcarboxamidoadenosine

Tris tris (hydroxymethyl)]aminomethane

XAC (8-[4-[[[[(2-aminoethyl)amino]-carbonyl]methyl]oxy]phenyl]-1,3-

dipropylxanthine)

\section{References}

1. Dalziel HH, Westfall DP. Pharmacol Rev. 1994; 46:449-466. [PubMed: 7899473]

2. Kizaki H, Suzuki K, Tadakuma T, Ishimura Y. J Biol Chem. 1990; 256:5280-5284. [PubMed: 1690738]

3. Szondy Z. Biochem J. 1994; 304:877-885. [PubMed: 7818494]

4. Tanaka Y, Yoshihara K, Tsuyuki M, Kamiya T. Exp Cel Res. 1994; 213:242-252.

5. Arends MI, Morris RS, Wyllie AH. Am J Pathol. 1991; 136:593-608. [PubMed: 2156431]

6. Tomei, LD.; Cope, FO. Apoptosis: The Molecular Basis of Cell Death. Cold Spring Harbor Lab; Plainview, NY: 1991.

7. Collins SJ. Blood. 1987; 70:1233-1244. [PubMed: 3311197]

8. Lubbert M, Herrmann F, Koeffler HP. Blood. 1991; 77:909-924. [PubMed: 1847312]

9. Kaufmann SH. Cancer Res. 1989; 49:5870-5878. [PubMed: 2790800]

10. Del Bino G, Skierski JS, Darzynkiewicz Z. Cancer Res. 1990; 50:574-5750.

11. Gallo-Rodriguez C, Ji XD, Melman N, Siegman BD, Sanders LH, Orlina J, Pu Q, van Galen PJM, Stiles GL, Jacobson KA. J Med Chem. 1994; 37:636-646. [PubMed: 8126704]

12. Kim HO, Ji XD, Siddiqi SM, Olah ME, Stiles GL, Jacobson KA. J Med Chem. 1994; 37:36143621. [PubMed: 7932588]

13. Gorczyca W, Gong J, Ardelt B, Traganos F, Darzynkiewicz Z. Cancer Res. 1993; 53:3186-3192. [PubMed: 8319228]

14. Sei Y, von Lubitz DKJE, Basile AS, Borner MM, Lin RCS, Skolnick P, Fossom LH. Neurosci Lett. 1994; 171:179-182. [PubMed: 8084486]

15. Chomczynski P, Sacchi N. Anal Biochim. 1987; 162:156-159.

16. Sajjadi FG, Firestein GS. Biochem Biophys Acta. 1993; 1179:105-107. [PubMed: 8399349]

17. Salvatore CA, Jacobson MA, Taylor HE, Linden J, Johnson RG. Proc Natl Acad Sci USA. 1993; 90:10365-10369. [PubMed: 8234299]

18. Del Bino G, Lassota P, Darzynkiewicz Z. Exp Cell Res. 1991; 193:27-35. [PubMed: 1995300]

19. Ramkumar V, Wilson M, Dhanraj DN, Gettys TW, Ali H. J Immunol. 1995; 154:5436-5443. [PubMed: 7730645]

20. Abbracchio MP, Ceruti S, Barbieri D, Franceschi C, Malorni W, Biondo L, Burnstock G, Cattabeni F. Biochem Biophys Res Comm. 1995; 213:908-915. [PubMed: 7654253]

21. Cheson BD, Vena DA, Foss FM, Sorensen JM. J Clin Oncol. 1994; 12:2216-2228. [PubMed: 7931492]

22. Zhou QY, Li C, Olah ME, Johnson RA, Stiles GL, Civelli O. Proc Natl Acad Sci USA. 1992; 89:7432-7436. [PubMed: 1323836] 
23. Linden J, Taylor HE, Robeva AS, Tucker AL, Stehle J, Rivkes SA, Fink JS, Reppert SM. Mol Pharmacol. 1993; 44:524-532. [PubMed: 8396714]

24. Jacobson KA, Kim HO, Siddiqi SM, Olah ME, Stiles GL, von Lubitz DKJE. Drugs of the Future. 1995; 20:689-699. [PubMed: 25242859]

25. Ramkumar V, Stiles GL, Beaven MA, Ali H. J Biol Chem. 1993; 268:16887-16890. [PubMed: 8349579]

26. Siddiqi SM, Jacobson KA, Esker JL, Melman N, Tiwari KN, Secrist JA, Schneller SW, Cristalli G, Johnson CA, Ijzerman AP. J Med Chem. 1995; 38:1174-1188. [PubMed: 7707320]

27. Daly JW, Padgett W. Biochem Pharmacol. 1992; 43:1089-1093. [PubMed: 1554381]

28. Robertson LE, Chubb S, Meyn RE, Story M, Ford R, Hittelman WN, Plunkett W. Blood. 1993; 81:143-150. [PubMed: 8093345]

29. Abbracchio MP, Brambilla R, Ceruti S, Kim HO, von Lubitz DKJE, Jacobson KA, Cattabeni F. Mol Pharmacol. 1995; 48:1038-1045. [PubMed: 8848003] 


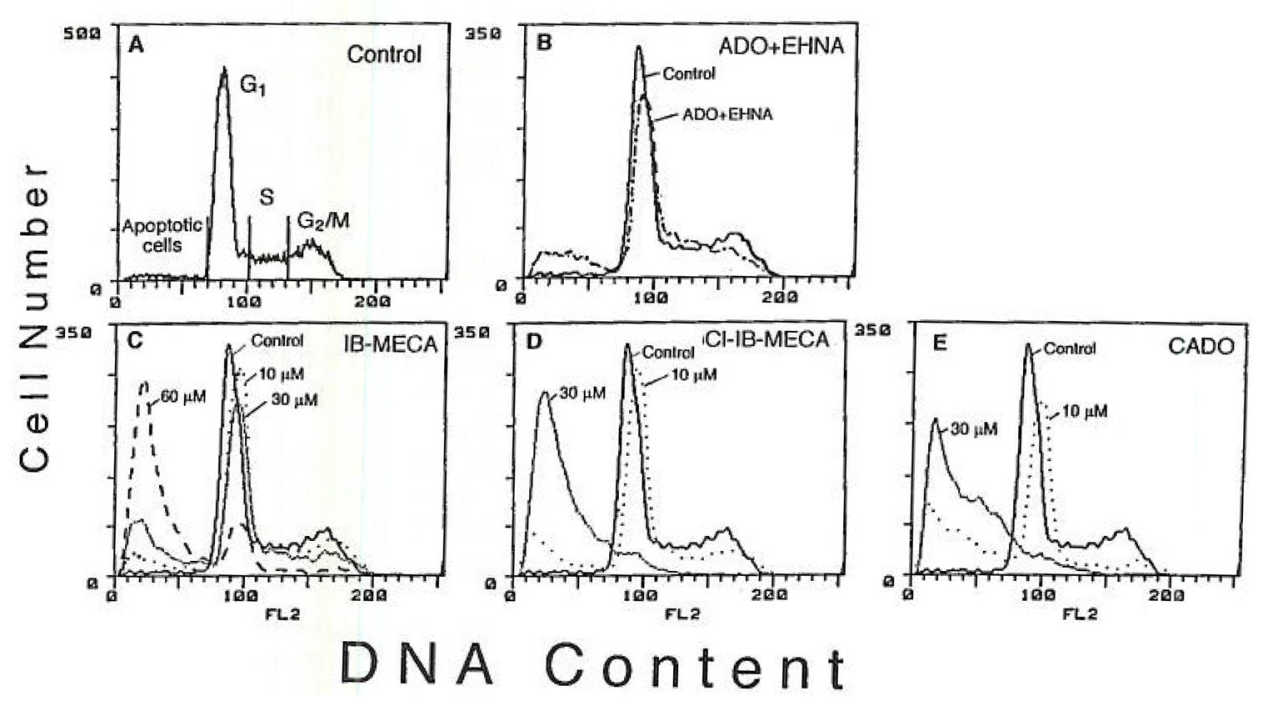

FIG. 1.

Flow cytometric DNA analysis of HL-60 cells determined by fluorescent cell sorting. The histograms were generated using chromomycin A3-stained cells that had been pretreated for $48 \mathrm{~h}$ with various adenosine agonists. Control cells are shown in A, and agonists used were (B) $100 \mu \mathrm{M}$ ADO (in the presence of the adenosine deaminase inhibitor EHNA, $100 \mu \mathrm{M}$ ), (C) IB-MECA (10-60 $\mu \mathrm{M}$, as shown), (D) CI-IB-MECA (10 or $30 \mu \mathrm{M}$, as shown), (E) CADO (10 or $30 \mu \mathrm{M}$, as shown). The horizontal and vertical axes refer to log fluorescence intensity and relative cell number, respectively. 

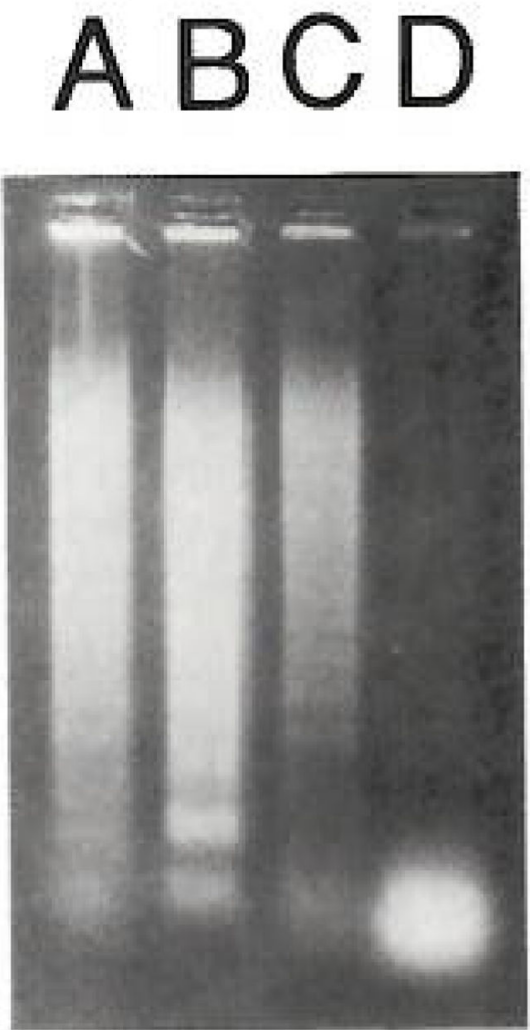

FIG. 2.

Agarose gel electrophoresis of DNA from cells treated with (Lane A) CADO (30 $\mu \mathrm{M})$. (Lane B) CI-IB-MECA (30 $\mu \mathrm{M})$, (Lane C) camptothecin (150 nM), or (Lane D) Control (strong spot in lower MW range is likely partially degraded RNA). 

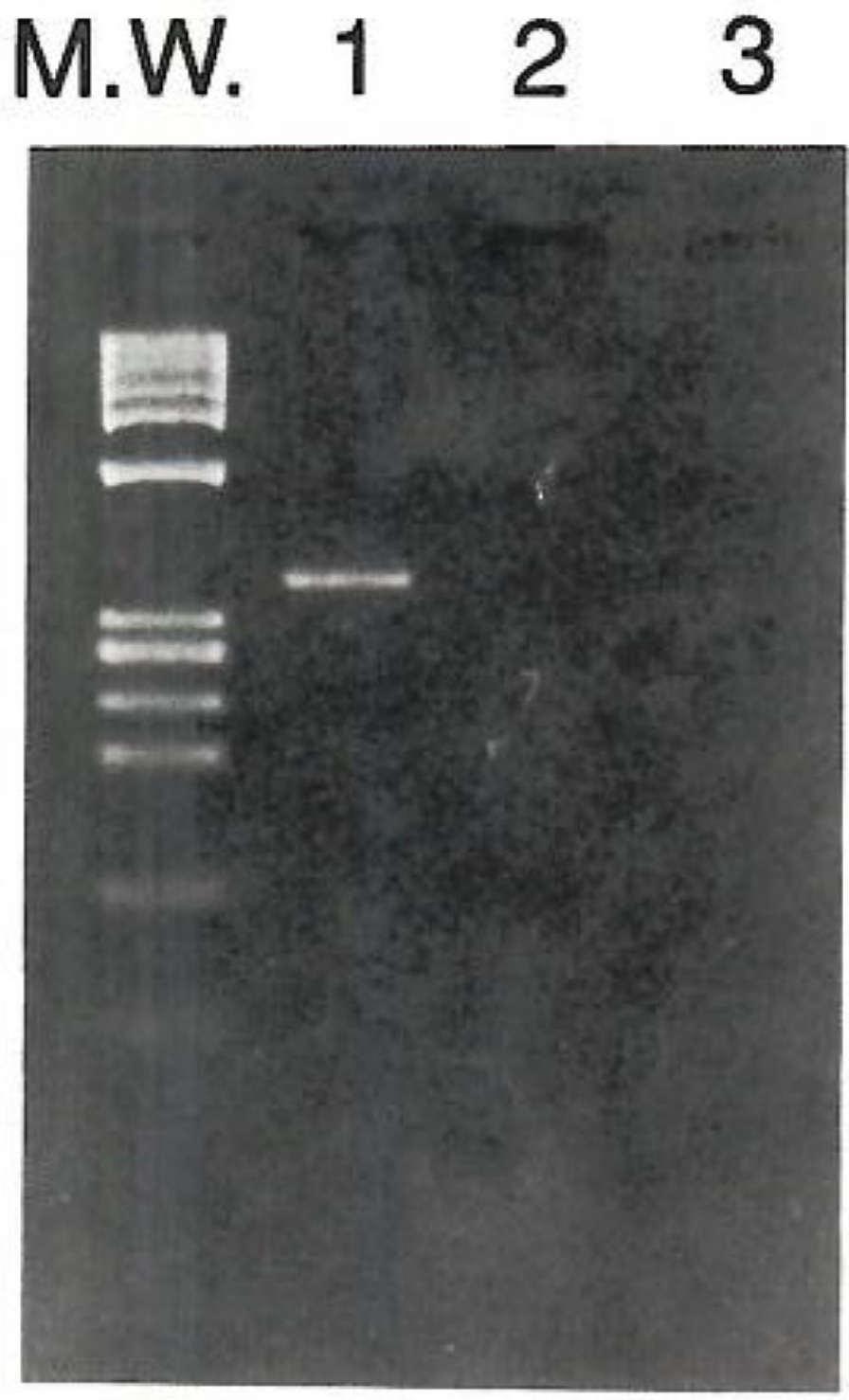

FIG. 3.

RT-PCR products obtained from HL-60 cells and separated on a 4\% NuSieve 3:1 agarose gel. The PCR product in Lane 2 is 361 bp long (situated between molecular weight markers for 310 and $613 \mathrm{bp}$ ), according to the human $\mathrm{A}_{3}$ adenosine receptor sequence. (Lane 3) Control without reverse-transcriptase, and (Lane 4) water substituted for the cDNA. 

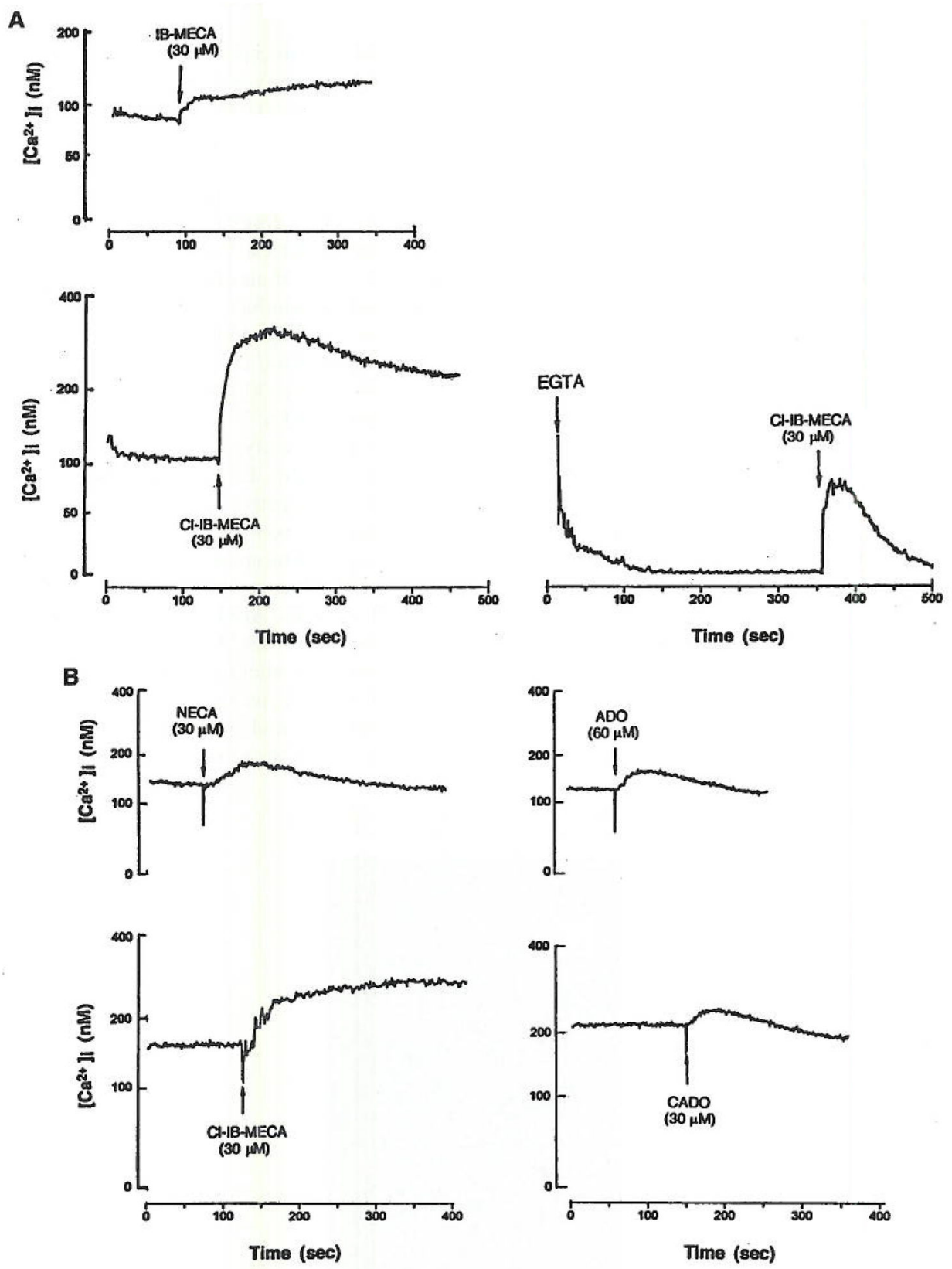

FIG. 4.

Effect of adenosine agonists on intracellular $\mathrm{Ca}^{2+}$ levels in HL-60 cells. Cells were prelabeled with Fluo-3AM, as described in Materials and Methods. Effects of CI-IB-MECA $(30 \mu \mathrm{M})$ in the absence or presence of $0.5 \mathrm{mM}$ EGTA. The basal $\left[\mathrm{Ca}^{2+}\right]$ level was calculated to be in the range of $40-200 \mathrm{nM}$. 